\title{
Mortality in Finland 1808-1809, 1917-1918 and 1939-1945
}

\author{
OIVA TURPEINEN
}

\author{
Assistant \\ Department of History \\ University of Helsinki
}

\section{Introduction}

Wartime events have interested researchers for a long time as a part of political history, for example, and therefore much has been written about them. Much less attention has been paid to studying the demographic significance of wars. How have wars affected the development of nuptiality, fertility and mortality? In what way is migration associated with wars? And what has been the significance of these demographic factors in the development of population size at different times?

This wide-ranging problem will be clarified in this article using the method of comparative research. Here this means that a closer look will be taken at the years 1808-1809, when Sweden-Finland was at war with Russia, the First World War years of 1917-1918, the latter year being the year of Civil War in Finland and, finally, the Second World War period of 1939-1945, which includes the Winter War of 1939-1940 and the Second Phase of the War 1941-1944.

\section{Previous research}

Works on local history tell about the persons killed in action in the wars mentioned above in very close detail. Often these descriptions are in the form of lists. These we will not examine further here.

Even at the national level, research with a demographic approach is rarely to be found. For example, in Joh. Rich. Danielson's - later Danielson-Kalmari - work (1896) on the War of 1808-1809 and Finnish soldiers in 1808 and 1809 mortality is mentioned only in passing.

A very limited look at mortality but one focussed all the more on background factors is found in K. E. Lindén's work of 1908 titled Sjukvård och läkare under kriget 1808-1809. Later research on the War of 1808-1809 usually refers to this work, in particular (for example, Osmonsalo, 1947).

The studies made by Paavolainen on the violent events of $1918(1966,1967)$ are already classic. In these and in his 1971 study on prisoner-of-war camps Paavolainen makes a much broader and more thorough examination of the question than previous works describing the events of 1918 (for example: Finland's Frihetskrig år 1918, 1925). Mention is made here on the following works on political and administrative history, which touch on demographic questions: Polvinen, 1967 and 1971; Manninen, 1974; Holodovski, 1978; Upton, 1980; Lappalainen, 1981 and Piilonen, 1982. The most significant research is from the year 1970: Tor Hartman, Dead and disappeared persons in the Civil War in 1918).

No work similar to Hartman's exists concerning the years 1939-1944. These matters are touched on by, among others, Järvinen (1948, 1950), Niukkanen (1951), Holsti 
(1955, 1956, 1957), Oesch (1956), Airi and Rafael Koskimies (1964), Ahto (1980), Numminen (1981) and Myllyniemi (1982). A brief glimpse at the demographic aspect and then mainly at the number killed in action appears also in the extensive series Suomen sota 1941-1945, 11 vols. (1950-1975) and Talvisodan historia, 4 vols. (1977-1979). In the fourth part of the latter series Vuorenmaa, in particular, estimates the losses of the Winter War.

\section{The losses: 205000 persons}

It is, of course, somewhat speculative to calculate to what extent war, as such, affected the excess mortality of 1808 - 1809, 1917-1918 and 1938-1944. The years of the War of 1808-1809, above all, are problematic. Even in times of peace, mortality in the preindustrial era rose to great heights, as in 1867-1868, for example. What if the mortality of $1808-1809$ would have increased more than usual even without the war?

These reservations should be borne in mind when discussing excess mortality. When calculating excess mortality the mortality levels of six years before and six years after the crisis have been included. By interpolating these, a »normal mortality» has been estimated for the crisis years; anything above this is excess mortality.

With this method the losses of $1808-1809$ came to 60000 persons, of $1917-1918$ to about 50000 persons and of 1939-1944 to around 95000 persons, or a total of 205000 Finns made up the extra harvest reaped by Death.

\section{Four out of five were males}

The more than 200000 persons who lost their lives were distributed as can be expected - quite unequally by sex, as is shown by the following figures:

\begin{tabular}{|c|c|c|c|c|}
\hline \multirow[t]{2}{*}{ Period } & \multicolumn{2}{|c|}{ Number of deaths } & \multicolumn{2}{|c|}{ Excess mortality (number) } \\
\hline & Male & Female & Male & Female \\
\hline 1808 & 27070 & 26854 & & \\
\hline 1809 & 25705 & 25824 & & \\
\hline $1808-1809$ & 52775 & 52678 & 30000 & 30000 \\
\hline $\begin{array}{l}1917 \\
1918\end{array}$ & $\begin{array}{ll}30 & 327 \\
62 & 160\end{array}$ & $\begin{array}{l}28536 \\
32942\end{array}$ & & \\
\hline $1917-1918$ & 92487 & 61478 & 40500 & 9500 \\
\hline 1939 & 30570 & 23730 & & \\
\hline 1940 & 47903 & 25793 & & \\
\hline 1941 & 51112 & 22801 & & \\
\hline 1942 & 33718 & 22564 & c64) & 20 \\
\hline 1943 & 28494 & 21585 & & \\
\hline 1944 & 43649 & 24636 & & \\
\hline $1939-1944$ & 235446 & 141109 & 94000 & 1000 \\
\hline Total & 327933 & 255265 & 164500 & 40500 \\
\hline
\end{tabular}

During these three periods of crisis the total male excess mortality was 164500 persons or around $80 \%$ and female excess mortality totalled 40500 persons or $20 \%$.

The most surprising factor in the above figures, however, is their developmental trend. In the years $1808-1809$ the excess mortality of males and females was about the same. On the other hand, in 1917-1918 the main stress in excess mortality was already clearly on the males and in 1939-1944 almost all were males. 


\section{Sources and method}

The following examination of the excess mortality problem will be based on statistical sources. For the years 1917-1918 and 1939-1944 published statistical series are available (population and population change tables and cause of death tables). On the other hand, for 1808-1809 we must rely on material from the archives of the Central Statistical Office of Finland.

The use of this archival material is all the more necessary because the problem will be examined by month and by age group. Data by age group is available for both sexes together (Turpeinen, 1973), but not for males and females separately. The Central Statistical Office data for 1808-1809 is recorded by town and for rural areas by deanery, so that monthly age group data for the entire country can only be obtained by adding together the data for the towns and the deaneries.

In order to compare monthly mortality figures, the mean population figure for each month must be calculated, and the number of deaths compared with this figure. The fact that the months of the year are different in length must also be taken into account in the calculations. In addition, monthly mortality figures have been made commensurate with annual mortality figures (for method, see Turpeinen, 1978, 1979 and 1981).

Before we calculate monthly and age group ratios, we should examine the number of births and deaths and their difference each month for the three crisis periods mentioned.

\section{Births and deaths by month}

\section{The War of 1808-1809}

Figure 1 shows how the number of deaths was about the same month for month for both males and females. They rose and fell hand in hand. The number of deaths exceeded births already in early 1808. The first peak was reached in May 1808 and the second in September of the same year. At the end of 1808 mortality again began to rise and remained at an extremely high level until May 1809. In the latter half of 1809 the number of deaths decreased rapidly and dropped below the number of births during the last two months of the year.

The approximately equal number of female and male deaths and their distribution over the different months at about the same rate shows that high numbers of persons killed on the battlefield could not have been behind the high mortality. The main reasons must be looked for elsewhere, as is done further on.

With the number of deaths exceeding births month after month, the population of Finland naturally decreased. Thus the number of males dropped from 427300 in January 1808 to 401100 in October 1809, the number of females dropped respectively from 465200 to 448200 . The entire population thus decreased during this period from 892600 to 849200 persons or by 43400 persons.

\section{The years 1917-1918}

The second crisis period is associated with the years 1917-1918, when violence in many forms occurred in Finland. The Czar was overthrown in March 1917. In early November of the same year the Bolshevik Revolution took place in St. Petersburg and its shock waves were felt strongly in Finland. Already that November a general strike was held accompanied by political murders and other acts of violence. After Finland declared independence (on December 6th) tension between the conflicting forces increased. There were the White forces on one side and on the other, the Reds, who were supported by the Soviet Russian Government and by Russian military units stationed in Finland. Armed conflict began at the end of January 1918; 
F i g u r e 1. Number of births and deaths for males and females by month in Finland 1808-1809.
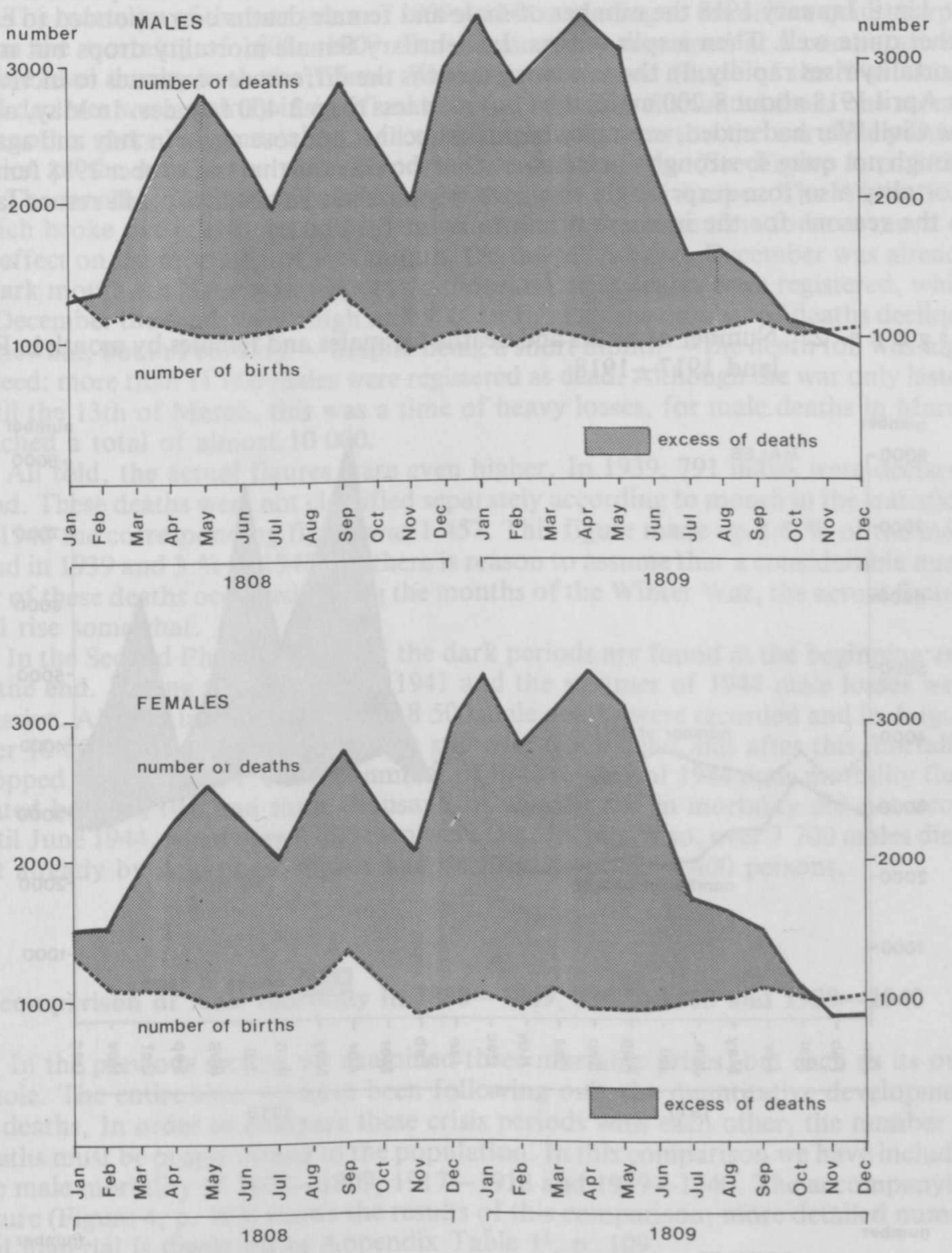

before long the war of independence evolved all the more clearly into a civil war, although to a great extent it was also a war between Finland and Soviet Russia. Although the actual events of war ended by May 1918, the bloody aftermath was still to come with executions and deaths in prisoner-of-war camps.

How did these turbulent times affect male and female mortality? In 1917 the number of deaths was at its highest in March. This cannot be directly related, however, to the March Revolution, that is the fall of the Czar, even though acts of violence occurred also in Finland. Death rates in the early part of the year were traditionally higher than at the end of the year (Turpeinen, 1979). Later development also followed the same pattern. For example, in the period 1871-1890 March was the month of peak mortality (Population tables VI, 33 1902, pp. 414-415). 
Figure 2 also shows that in March 1917 mortality did not rise significantly. This shows that murders were more an individual occurrence than a mass phenomena.

Until January 1918 the number of male and female deaths corresponded to each other quite well. Then a split occurs. In February female mortality drops but male mortality rises rapidly. In the following months the difference continues to increase. In April 1918 about 8200 males died but only less than 2400 females. In May, after the Civil War had ended, mortality began to decline, but rose again in July and again, though not quite so strongly, in October. One should note that in October 1918 female mortality also rose surprisingly to a level higher than fertility. We will return later to the reasons for the increase in mortality at the end of 1918 .

F i g u r e 2. Number of births and deaths for males and females by month in Finland 1917-1918.
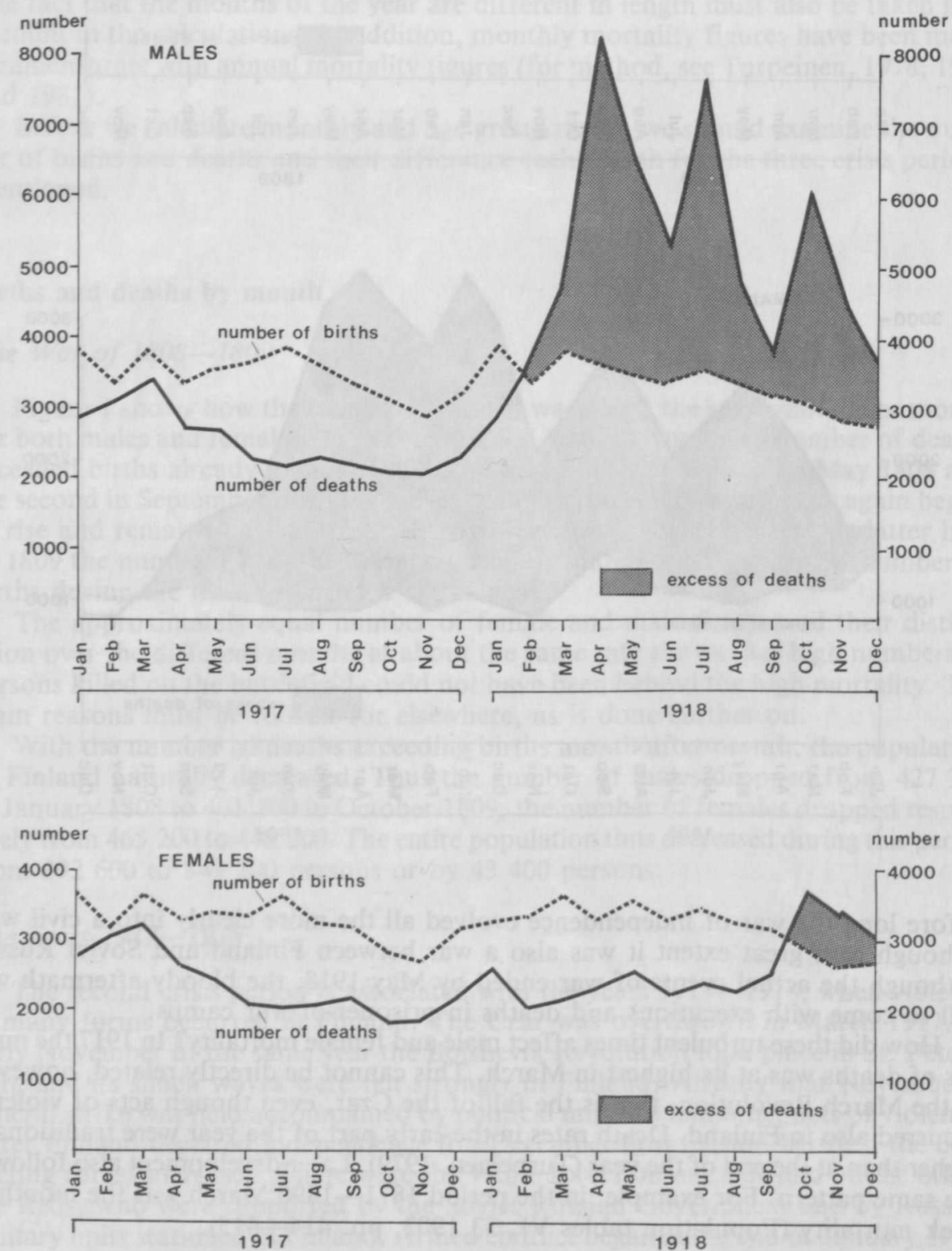
The Winter War, 1939-1940 and the Second Phase of the War, 1941-1944

The mortality of the war years of 1939-1944 according to sex differs quite sharply from the mortality of $1808-1809$. Female mortality remained at a comparatively stable level during both the Winter War and the Second Phase of the War. Rises and declines were entirely insignificant. In fact, fertility fluctuated from one month to another more than mortality, a fact indirectly due in part to the war. The participation of the men in the war, of course, affected fertility. (See Figure 3, p. 102)

The monthly fluctuations of male mortality were all the sharper. The Winter War which broke out at the end of November 1939 did not have time to have much of an effect on the mortality of that month. On the other hand, December was already a dark month. In November about two thousand male deaths were registered, while in December the total was as high as 7400 . In January the number of deaths declined somewhat, but in February - despite being a short month - the death toll was high indeed: more than 11000 males were registered as dead. Although the war only lasted until the 13th of March, this was a time of heavy losses, for male deaths in March reached a total of almost 10000 .

All told, the actual figures were even higher. In 1939, 791 males were declared dead. These deaths were not classified separately according to month in the statistics. In 1940 the corresponding figure was 1457 . This figure made up $2.6 \%$ of the male dead in 1939 and $3 \%$ in 1940 . As there is reason to assume that a considerable number of these deaths occurred during the months of the Winter War, the actual figures will rise somewhat.

In the Second Phase of the War the dark periods are found at the beginning and at the end. During the summer of 1941 and the summer of 1944 male losses were massive. Already in July 1941 about 8500 male deaths were recorded and in August over 10 000. In September there were still over 6500 dead, but after this mortality dropped significantly. From the summer of 1942 to May of 1944 male mortality fluctuated between two and three thousand. A sudden rise in mortality did not occur until June 1944, when over 8000 men were lost. In July, also, over 7700 males died, but already by August the figure had declined to under 4400 persons.

\section{A comparison of male mortality in 1808 - 1809, 1917-1918 and 1939-1940}

In the previous section we examined three mortality crises, but each as its own whole. The entire time we have been following only the quantitative development of deaths. In order to compare these crisis periods with each other, the number of deaths must be proportioned to the population. In this comparison we have included the male mortality of $1808-1809,1917-1918$ and 1939-1940. The accompanying figure (Figure 4, p. 103) shows the results of this comparison; more detailed numerical material is displayed in Appendix Table $1^{1}$, p. 109.

Of the three crisis periods, the highest monthly mortality was found in April 1809, as high a total as 100.3 per thousand. In general, mortality peaks in $1808-1809$ were clearly higher in several different months than in 1918 or during the Winter War of 1939-1940. On the other hand, the peak mortality of the Winter War, in February 1940 , already comes quite close to the worst monthly figures of $1808-1809$.

In other respects, however, the monthly developmental curves for male mortality in 1808-1809 and 1939-1940 differ from each other. Before the Winter War mor-

${ }_{1}$ The following should be mentioned concerning the calculation of the monthly mortality figures in Figure 4. The number of deaths per month has first been proportioned to the mean population figure per 1000 persons of that particular month. The value for February has been multiplied by 12.62 , the values of 31-day months by 11.81 and 30 -day months by 12.2 . Thus we have made not only the different crisis periods but also the different months commensurate with each other. 


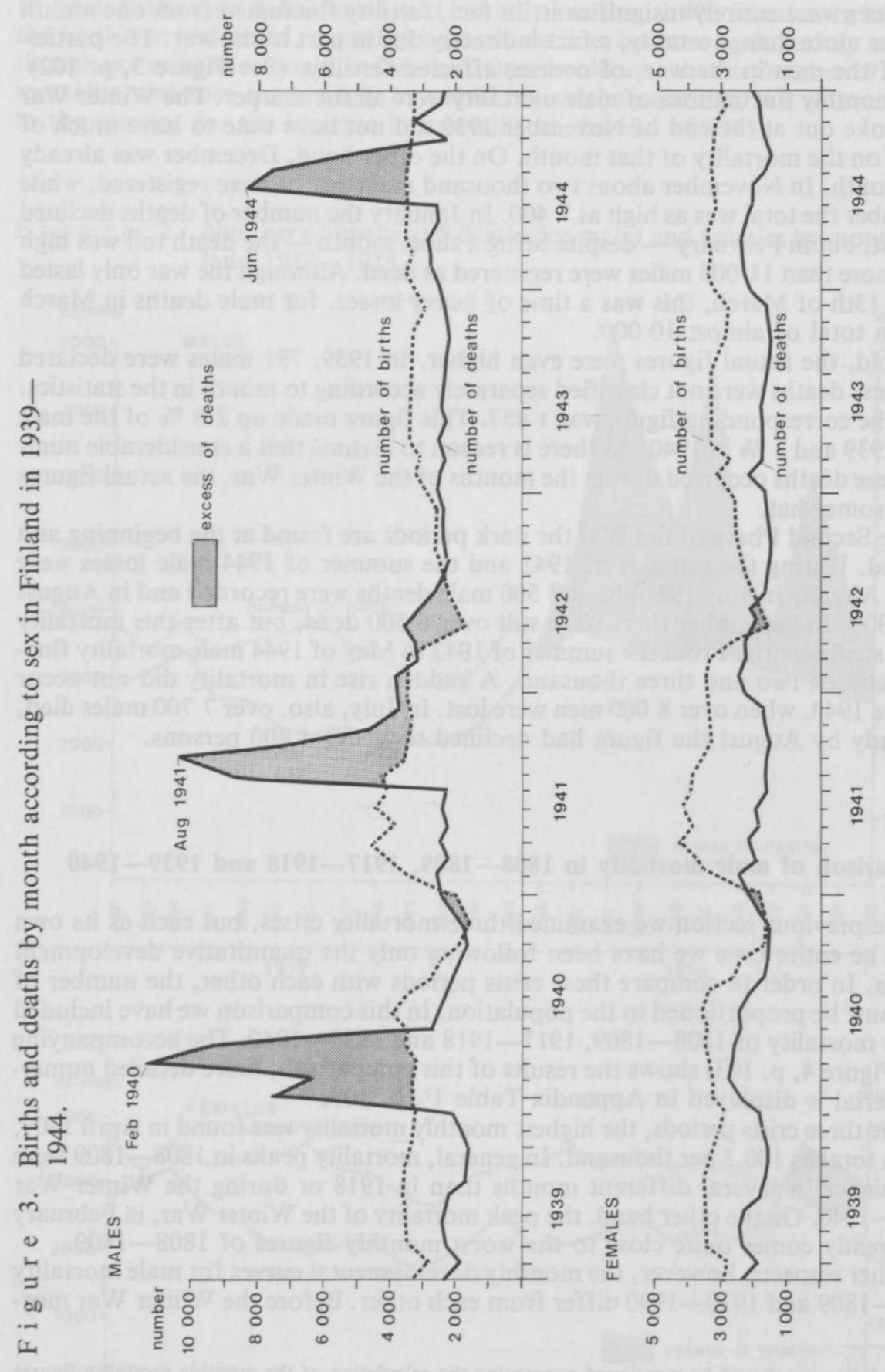


F i g u r e 4. Male mortality by month in Finland 1808-1809, 1917-1918 and 1939-1940.

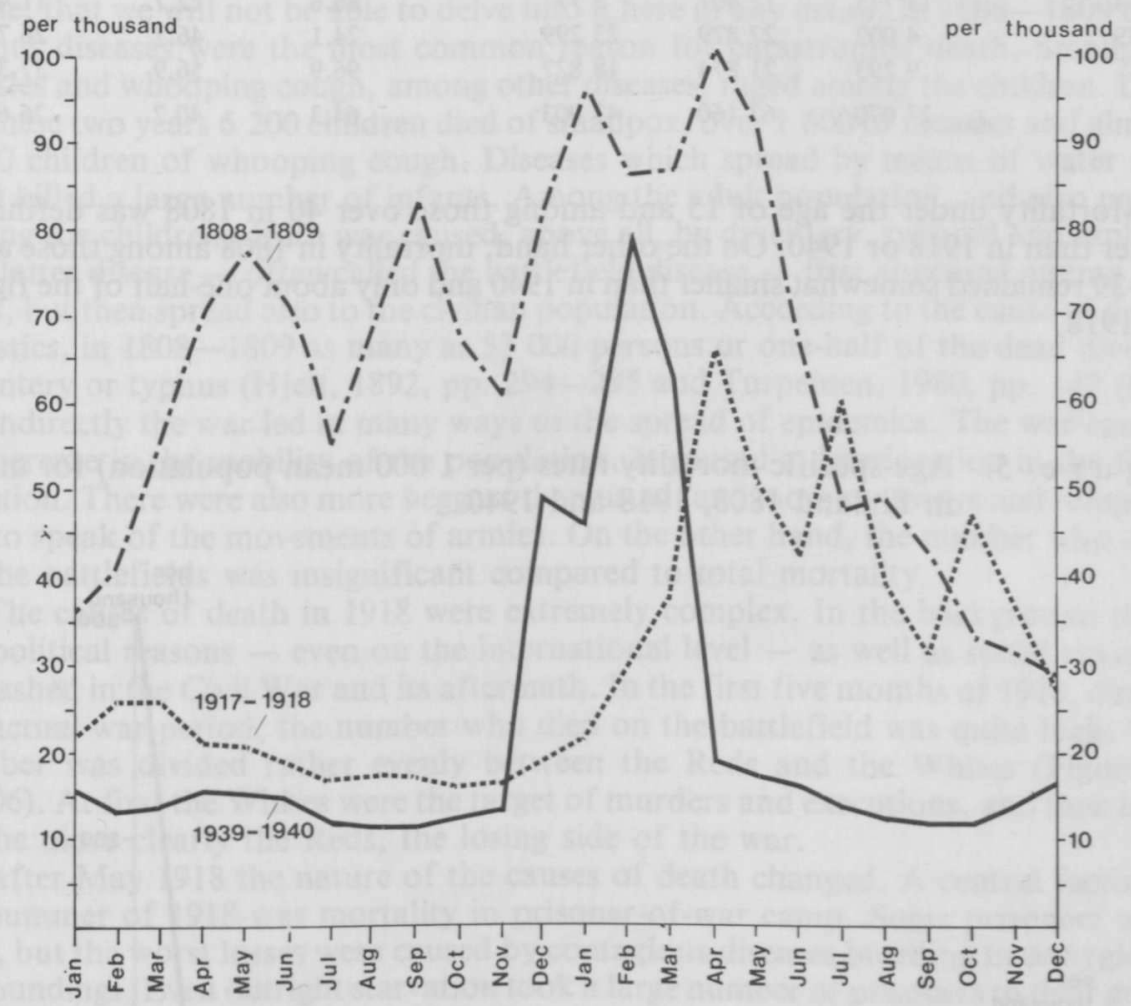

tality was at a low level and directly after the war it dropped again to about the same level.

Between the two mortality crises, in a sort of intermediate zone, we find the mortality of the Civil War of 1918. After the actual events of the Civil War mortality continued to be very high and the figures for the end of 1918 rose higher at times than in the latter half of 1809.

\section{Male mortality by age group in 1808,1918 and 1940}

In light of the above, it is important to analyze the age structure of the deaths. A closer examination was made of the years 1808,1918 and 1940 . In order to compare with each other the deaths occurring during these years in different age groups, age-specific mortality rates must be calculated. This has been done and the results can be seen in Appendix Table 2, p. 109 and in the accompanying Figure 5, p. 104.

A first glance already shows that the age-specific mortality curve of 1808 differs sharply from that of 1918 and 1940 . The mortality of males under the age of 10 and over the age of 40 in 1808 was unusually high compared to 1918 and especially compared to the mortality of 1940 . Thus, for example, mortality among 0-4-year-olds in 1808 was about six times as high as that of 1940 and over three times as high as the mortality of 1918. If the male age-specific mortality of these three crisis years is divided into three main groups, we arrive at the following table: 
Age Number of deaths

Age-specific mortality

$\begin{array}{lrrrrrr} & 1808 & 1918 & 1940 & 1808 & 1918 & 1940 \\ 0-14 & 13775 & 12407 & 5777 & 86.6 & 22.7 & 11.4 \\ 15-39 & 4002 & 27879 & 23299 & 24.1 & 46.7 & 26.7 \\ 40+ & 9293 & 21874 & 18827 & 96.9 & 56.9 & 37.3 \\ \text { Total } & 27070 & 62160 & 47903 & 64.3 & 40.7 & 26.6\end{array}$

Mortality under the age of 15 and among those over 40 in 1808 was definitely higher than in 1918 or 1940 . On the other hand, mortality in 1808 among those aged 15-39 remained somewhat smaller than in 1940 and only about one-half of the figure for 1918.

F i g u r e 5. Age-specific mortality rates (per 1000 mean population) for males in Finland 1808, 1918 and 1940.

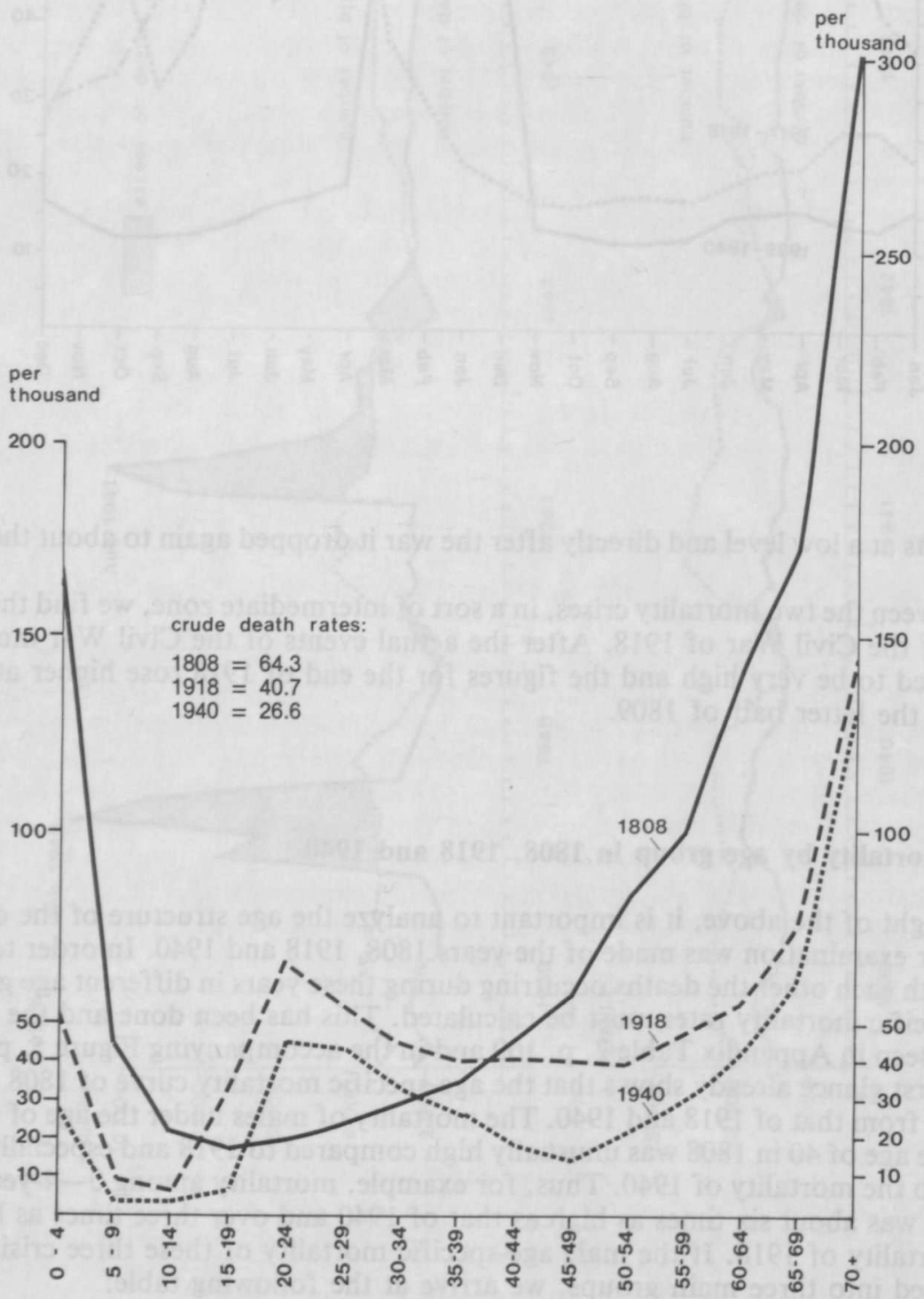




\section{Causes of death}

The problem of causes of death in these three periods of crisis forms such a large whole, that we will not be able to delve into it here in any detail. In 1808-1809 contagious diseases were the most common reason for catastrophic death. Smallpox, measles and whooping cough, among other diseases, raged among the children. During these two years 6200 children died of smallpox, over 1600 of measles and almost 4000 children of whooping cough. Diseases which spread by means of water and food killed a large number of infants. Among the adult population, and also partly among the children, death was caused, above all, by dysentery, typhoid and typhus. The latter disease - often called the battlefield disease - first appeared among soldiers, but then spread also to the civilian population. According to the cause of death statistics, in 1808-1809 as many as 53000 persons or one-half of the dead died of dysentery or typhus (Hjelt, 1892, pp. 294-295 and Turpeinen, 1980, pp. 147 ff.).

Indirectly the war led in many ways to the spread of epidemics. The war caused an increase in the mobility of the population. It caused a deterioration in the food situation. There were also more beggars than usual, and more runaways and refugees, not to speak of the movements of armies. On the other hand, the number who died on the battlefields was insignificant compared to total mortality.

The causes of death in 1918 were extremely complex. In the background there are political reasons - even on the international level - as well as social reasons, unleashed in the Civil War and its aftermath. In the first five months of 1918, during the actual war period, the number who died on the battlefield was quite high. The number was divided rather evenly between the Reds and the Whites (Figure 6, p. 106). At first the Whites were the target of murders and executions, and then later all the more clearly the Reds, the losing side of the war.

After May 1918 the nature of the causes of death changed. A central factor in the summer of 1918 was mortality in prisoner-of-war camp. Some prisoners were shot, but the worst losses were caused by contagious diseases breeding in unhygienic surroundings. Even outright starvation took a large number of prisoners to their grave according to Paavolainen's study (1971).

July was the darkest month in the prisoner-of-war camps, which goes far to explain the second peak in mortality in 1918. On the other hand, the third peak found in October is problematic (see Figure 2 shown earlier). According to Paavolainen's study $(1971$, p. 330$)$, there were 4700 women in the prisoner-of-war camps, 83 of whom died and they during the summer, so this does not explain the mortality of late 1918 . Figure 6 also shows that male mortality in the prisoner-of-war camps also dropped sharply toward the end of 1918 .

The mortality of late 1918 would necessitate further studies. For now we can assume that contagious diseases perhaps spread from the prisoner-of-war camps to the rest of the population, thus resulting also in a rise in female mortality. It is true that after September 1918 prisoners were released, and this development was hastened by the decree of amnesty made by P. E. Svinhufvud in October.

Compared to the year of Civil War the unusually high mortality of males and especially 20-39-year-old males during the Winter War is demographically quite clear. The dominant cause was mortui in bello. In 1939-1940 this was the cause of death in the various age groups as follows:

\begin{tabular}{lcc} 
Age & \multicolumn{2}{c}{ Mortui in bello } \\
& Number & $\%$ \\
under 20 & 386 & 1.6 \\
$20-24$ & 6787 & 28.7 \\
$25-29$ & 7579 & 32.0 \\
$30-34$ & 4883 & 20.7 \\
$35-39$ & 2907 & 12.3 \\
over 40 & 1123 & 4.7 \\
Total & 23665 &
\end{tabular}


F i g u r e 6. Number of dead males in the Civil War of the year 1918 by month of death and cause of death.

Source: Hartman 1970, p. 19-22.
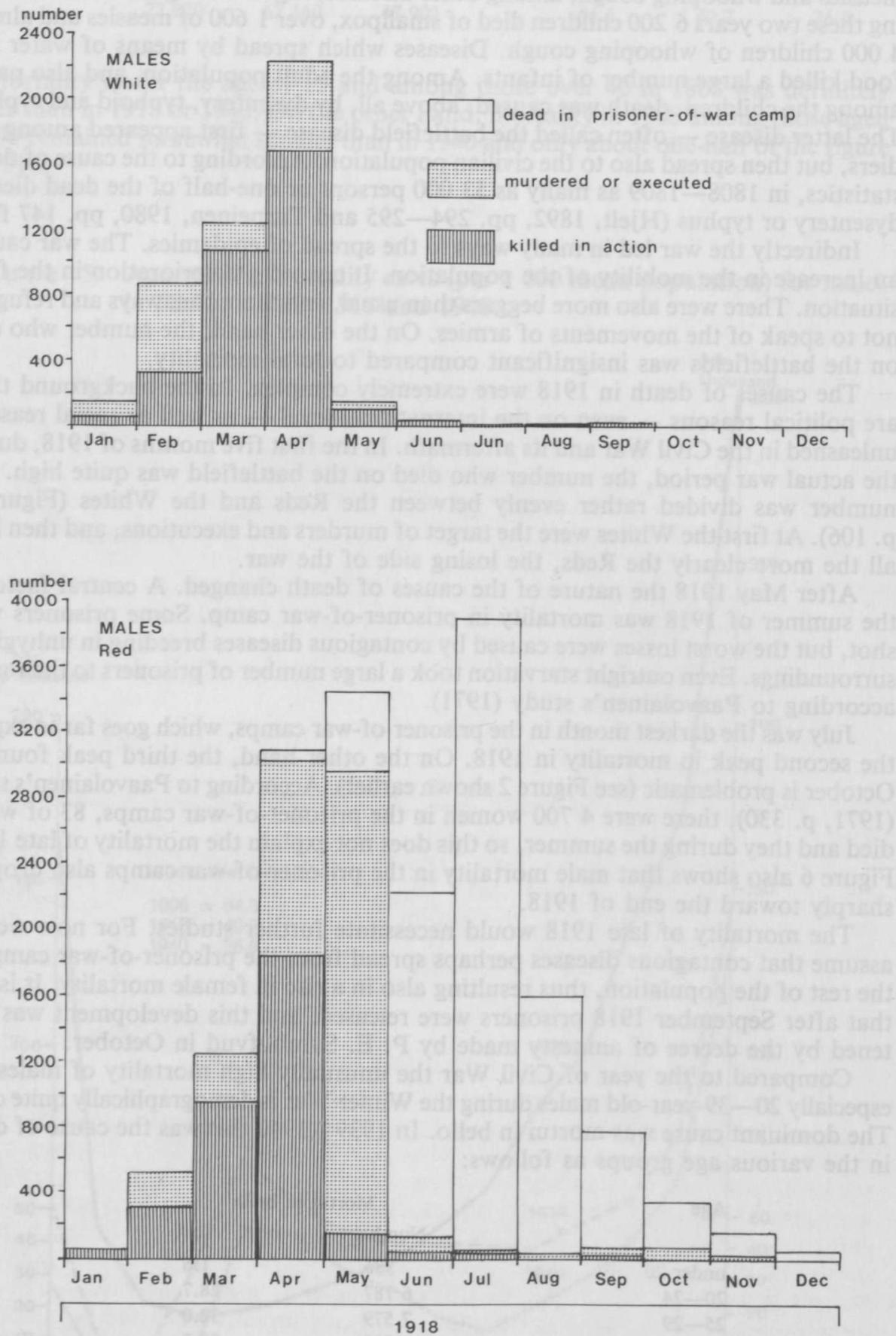
When we bear in mind that in 1939-1940 about 49500 females and 78500 males died, meaning a difference of about 29000 , mortui in bello alone as a cause of death explains over $80 \%$ of the said difference. In addition, this percentage is actually even greater, if we include the 2420 persons declared dead at least one-third of whom disappeared in the tumult of the Winter War.

\section{Discussion}

The three crisis periods examined above occurred in phases differing in regard to demographic development. The War of $1808-1809$ took place at a time when contagious diseases were still a mighty force, although their power was partly crumbling. This period had apparently continued for as long as humans had been on the earth. Epidemics had been closely associated with wars, and this had significantly prevented population growth. A crumbling of power can be spoken of in part because in the early 1800 s vaccination against smallpox was begun, but mainly because the plague had disappeared from Europe in the 1700s, and it has not reappeared after that to any significant extent. The plague, in particular, had been a mighty killer for a long time when its path joined up with that of wars. It has often been a matter of dispute whether the disease Thycydides mentioned in his description of the Peloponnessian War was the plague or some other epidemic. In any case, the plague later made havoc in connection with many wars, in Finland most recently in 1710 during the so-called Northern War (1700-1721). Although the plague disappeared after 1710 from Finland, many other epidemics were to come, which was clearly apparent during the War of 1808-1809. The mortality of the Civil War in 1918, though, occurred during a time of so-called demographic transition. Mortality and fertility were declining and the proportion of death by contagious disease was also greatly decreasing. In unfavorable surroundings, among soldiers, for example, and especially in prisoner-of-war camps, the significance of contagious disease often rose greatly, a lesson hard-learned in the summer of 1918.

The mortality of 1939-1944 occurred, on the other hand, during a phase when mortality and fertility had already dropped to quite a low level and when contagious diseases could increasingly be controlled. Thus, for example, the small incidence of dysentery found among the Finnish forces in the Second Phase of the War was got under control and was of no significance, nor was there any fear that a wide epidemic of dysentery would spread among the civilian population as it did in $1808-1809$.

If an attempt is made to apply the traditional doctrine of total war to the three crisis periods examined, we face certain difficulties. The First and Second World War were total wars because all the resources of a nation - economic, spiritual, etc. were rushed to the altar of war. On the other hand, it is said that previously wars were Cabinet wars whose outcome was determined by armies with the civilian population remaining on the sidelines. Regarding mortality and population remaining on the sidelines. Regarding mortality and population growth this view is not entirely problem-free. It was particularly in the wake of earlier wars that epidemics spread, causing great losses to the civilian population. Population development often began to decline. On the other hand, in the First World War and even less in the Second World War a link of this kind between epidemics and mortality was no longer to be found. Thus in the Twentieth Century in the population development of Europe or the world, there has been no observable population catastrophe, no rapid and sudden decline in the population. Instead we find continuous growth despite there having been an enormous number of destructive and bloody wars. In this sense demographically - the wars of the previous centuries were really total wars and those of the 20th Century less than total. Or actually we should be careful to say: wars waged up to the year 1986 of the Twentieth Century, for when speaking of a nuclear war the concept "total» is, of course, - also demographically - only a weak expression. 


\section{References}

Ahto, Sampo (1980). Aseveljet vastakkain. Lapin sota 1944-1945. Hämeenlinna.

Danielson (Danielson-Kalmari), Joh. Rich. (1896). Suomen sota ja Suomen sotilaat vuosina 1808 ja 1809. Helsinki.

Finlands Frihetskrig àr 1918. VI. Helsingfors 1925.

Hartman, Tor (1970). Dead and disappeared persons in the Civil War in 1918. Tilastollisia tiedonantoja No. 46. Helsinki.

Hjelt, Otto E. A. (1892). Svenska och finska medicinalverkets historia 1663-1812. II. Helsingfors.

Holodkovski, Viktor (1978). Suomen työväen vallankumous 1918. Moskova.

Holsti, Wolf H. (1955, 1956, 1957). Suomen Sota 1939-1945. I-III. Keuruu.

Järvinen, Y. A. (1948). Suomalainen ja venäläinen taktiikka talvisodassa. Porvoo.

Järvinen, Y. A. (1950). Jatkosodan taistelut. Porvoo.

Koskimies, Airi and Rafael (1964). Suomen lotta. Katsaus lottajärjestön toimintaan. Helsinki.

Lappalainen, Jussi T. (1981). Punakaartin sota. 1-2. Helsinki.

Lindén, K. E. (1908). Sjukvård och läkare under kriget 1808-1809. Helsingfors.

Manninen, Ohto (1974). Kansannoususta armeijaksi. Asevelvollisuuden toimeenpano ja siihen suhtautuminen valkoisessa Suomessa kevättalvella 1918. Historiallisia tutkimuksia 95. Helsinki.

Myllyniemi, Seppo (1982). Suomi sodassa 1939-1945. Keuruu.

Niukkanen, Juho (1951). Talvisodan puolustusministeri kertoo. Porvoo.

Numminen, Antti (1981). Suomen reserviupseeriliiton historia 1931-1981. Hämeenlinna.

Oesch, K. L. (1956). Suomen kohtalon ratkaisu Kannaksella v. 1944. Helsinki.

Official Statistics of Finland VI. Väkiluvun-tilastoa 29, 33, 41. Pääpiirteet Suomen väestötilastosta vuosina 1750-1890 (population statistics, years 1750-1890). Helsinki 1899, 1902 and 1909.

Official Statistics of Finland VI. Nos. 53, 96, 99, A 102, B 101 (vital statistics and causes of death 1917-1918 and 1939-1944). Helsinki 1921, 1944, 1945, 1949 and 1949.

Osmonsalo, Erkki K. (1947). Suomen valloitus 1808. Porvoo.

Paavolainen, Jaakko (1966, 1967). Poliittiset väkivaltaisuudet Suomessa 1918. I-II. Helsinki.

Paavolainen, Jaakko (1971). Vankileirit Suomessa 1918. Helsinki.

Piilonen, Juhani (1982). Vallankumous kunnallishallinnossa. Helsinki.

Polvinen, Tuomo (1967, 1971). Venäjän vallankumous ja Suomi 1917-1920. I-II. Porvoo.

Suomen sota $1941-1945$. 1-11. 1950-1975.

Talvisodan historia 1-4. Porvoo 1977-1979.

Turpeinen, Oiva (1973). Ikäryhmittäinen kuolleisuus Suomessa vv. 1750-1970. Demometrinen selvitys.

Turpeinen, Oiva (1978). Infectious diseases and regional differences in Finnish death rates, 1749-1773. Population Studies 32: 523-533.

Turpeinen, Oiva (1979). Monthly Mortality in Finland in 1751-1806. Yearbook of Population Research in Finland, XVII. Helsinki.

Turpeinen, Oiva (1980). Die Sterblichkeit an Pocken, Masern und Keuchhusten in Finnland in den Jahren 1761 bis 1865 . In: A. E. Imhof (ed.) Mensch und Gesundheit in der Geschichte. Husum: Matthiesen Verlag.

Turpeinen, Oiva (1981). Mortalitetskrisen i Finland åren 1788-1791. In: Historisk Tidskrift för Finland 1981: 1, 14-34.

Upton, Anthony F. (1980). The Finnish Revolution 1917-1918. Minneapolis.

Väestötilasto VI. Väestönmuutokset ja kuolinsyyt 1917-1918, 1939-1944. Helsinki. (Suomen virallinen tilasto)

Väkiluvun-Tilastoa, 29, 33, 41. Suomen Väestötilastoa 1750-1890. I-III. Helsinki 1899, 1902 and 1909. (Suomen virallinen tilasto). 
A p pendix Table 1 . Mean population (1000), number of deaths and monthly mortality rates for males in Finland in 1808-1809, 1917-1918 and 1939-1940.

\begin{tabular}{lcccccccccc} 
Month & \multicolumn{3}{c}{ Mean population $(1000)$} & \multicolumn{3}{c}{ Number of deaths } & \multicolumn{2}{c}{ Monthly mortality rates } \\
& $1808-09$ & $1917-18$ & $1939-40$ & $1808-09$ & $1917-18$ & $1939-40$ & $1808-09$ & $1917-18$ & $1939-40$ \\
Jan & 427.3 & 1526.9 & 1783.8 & 1323 & 2920 & 2295 & 36.6 & 22.6 & 15.2 \\
Feb & 427.3 & 1526.4 & 1784.7 & 1395 & 3090 & 1951 & 41.2 & 25.5 & 13.8 \\
Mar & 426.8 & 1527.8 & 1785.8 & 1987 & 3402 & 2152 & 55.0 & 26.3 & 14.2 \\
Apr & 425.7 & 1528.4 & 1787.0 & 2453 & 2751 & 2329 & 70.3 & 22.0 & 15.9 \\
May & 424.2 & 1529.1 & 1788.2 & 2781 & 2712 & 2380 & 77.4 & 20.9 & 15.7 \\
Jun & 422.6 & 1530.3 & 1789.4 & 2467 & 2280 & 2173 & 71.2 & 18.2 & 14.8 \\
Jul & 421.5 & 1531.8 & 1791.0 & 1994 & 2193 & 1826 & 55.9 & 16.9 & 12.0 \\
Aug & 420.4 & 1533.3 & 1792.7 & 2458 & 2258 & 1711 & 69.1 & 17.4 & 11.3 \\
Sep & 418.8 & 1534.6 & 1792.7 & 2866 & 2175 & 1643 & 83.5 & 17.3 & 11.2 \\
Oct & 417.7 & 1535.7 & 1795.8 & 2384 & 2076 & 1889 & 67.4 & 16.0 & 12.4 \\
Nov & 416.0 & 1536.6 & 1797.0 & 2057 & 2098 & 2040 & 60.3 & 16.7 & 13.9 \\
Dec & 415.1 & 1537.4 & 1795.1 & 2883 & 2372 & 7390 & 82.0 & 18.2 & 48.6 \\
Jan & 413.0 & 1538.4 & 1790.5 & 3347 & 2824 & 6134 & 95.7 & 21.7 & 40.5 \\
Feb & 411.0 & 1538.8 & 1784.4 & 2821 & 3706 & 11035 & 86.6 & 30.4 & 78.0 \\
Mar & 409.2 & 1538.1 & 1777.6 & 3015 & 4999 & 9590 & 87.0 & 38.4 & 63.7 \\
Apr & 407.0 & 1535.3 & 1795.0 & 3347 & 8218 & 2702 & 100.3 & 65.3 & 18.4 \\
May & 404.8 & 1531.5 & 1776.1 & 3151 & 6493 & 2564 & 91.9 & 50.1 & 17.0 \\
Jun & 403.1 & 1529.0 & 1777.3 & 2185 & 5358 & 2318 & 66.1 & 42.8 & 15.9 \\
Jul & 402.2 & 1526.0 & 1778.2 & 1616 & 7695 & 2063 & 47.5 & 59.6 & 13.7 \\
Aug & 401.7 & 1523.2 & 1778.9 & 1653 & 4898 & 1900 & 48.6 & 38.0 & 12.6 \\
Sep & 401.3 & 1522.2 & 1779.2 & 1412 & 3895 & 1761 & 42.9 & 31.2 & 12.1 \\
Oct & 401.1 & 1520.4 & 1779.2 & 1130 & 6025 & 1858 & 33.3 & 46.8 & 12.3 \\
Nov & 401.1 & 1518.2 & 1779.0 & 1048 & 4524 & 2050 & 31.9 & 36.4 & 14.1 \\
Dec & 401.2 & 1517.0 & 1778.7 & 982 & 3525 & 2471 & 28.9 & 27.4 & 16.4
\end{tabular}

A p p e n dix T a b le 2. Mean population ( 1000$)$, number of deaths and agespecific mortality rates (per 1000 mean population) for males in Finland 1808, 1918 and 1940.

\begin{tabular}{lrrrrrrrrr} 
Age & \multicolumn{3}{c}{ Mean population $(1000)$} & \multicolumn{3}{c}{ Number of deaths } & \multicolumn{3}{c}{ Age-specific mortality rates } \\
& 1808 & 1918 & 1940 & 1808 & 1918 & 1940 & 1808 & 1918 & 1940 \\
$0-4$ & 62.9 & 181.2 & 173.5 & 10565 & 9459 & 4765 & 168.0 & 52.2 & 27.5 \\
$5-9$ & 49.4 & 188.2 & 161.4 & 2228 & 1819 & 550 & 45.0 & 9.7 & 3.4 \\
$10-14$ & 46.7 & 177.4 & 174.0 & 982 & 1129 & 462 & 20.9 & 6.4 & 2.7 \\
$15-19$ & 39.7 & 157.8 & 176.6 & 703 & 4905 & 1127 & 17.7 & 31.1 & 6.4 \\
$20-24$ & 35.8 & 130.5 & 153.2 & 693 & 8458 & 6697 & 19.4 & 64.8 & 43.7 \\
$25-29$ & 33.6 & 111.8 & 163.0 & 802 & 6136 & 6895 & 23.9 & 54.9 & 42.3 \\
$30-34$ & 30.1 & 105.6 & 157.9 & 884 & 4710 & 4941 & 29.4 & 44.6 & 31.3 \\
$35-39$ & 26.7 & 91.7 & 133.8 & 920 & 3670 & 3639 & 34.4 & 40.0 & 27.2 \\
$40-44$ & 24.2 & 83.9 & 112.2 & 1089 & 3370 & 2095 & 45.0 & 40.2 & 18.7 \\
$45-49$ & 20.2 & 72.5 & 93.2 & 1148 & 2839 & 1363 & 56.8 & 39.2 & 14.6 \\
$50-54$ & 16.3 & 55.8 & 81.8 & 1345 & 2195 & 1702 & 82.5 & 39.3 & 20.8 \\
$55-59$ & 12.9 & 52.6 & 68.4 & 1274 & 2422 & 2011 & 98.8 & 46.0 & 29.4 \\
$60-64$ & 9.3 & 42.8 & 55.1 & 1306 & 2362 & 2290 & 140.4 & 55.2 & 41.6 \\
$65-69$ & 6.1 & 34.0 & 42.6 & 1060 & 2537 & 2562 & 173.8 & 74.6 & 60.1 \\
$70+$ & 6.9 & 43.1 & 52.0 & 2071 & 6149 & 6804 & 300.1 & 142.7 & 130.8 \\
All & 420.8 & 1528.9 & 1798.7 & 27070 & 62160 & 47903 & 64.3 & 40.7 & 26.6
\end{tabular}

